\title{
KATILIMCI BÜTÇE ANLAYIŞININ TÜRKIYE AÇISINDAN DEĞERLENDİIILMESİ
}

Neslihan KOÇ*

Atıf/O: Koç, Neslihan (2017). Katılımcı Bütçe Anlayışının Türkiye Açısından Değerlendirilmesi, Hitit Üniversitesi Sosyal Bilimler Enstitüsü Dergisi, Yıl 10, Sayı 1, Haziran 2017, ss. 443-470

Özet: Mali politikalarla ilgili plan ve hedefler ile yaplacak harcamalar ve toplanacak gelirler, bütçe süreci içinde belirlenmektedir. Bütçenin önemli fonksiyonlarından biri olarak kabul edilen mali disiplinin sağlanabilmesi, devlet yönetiminde ve harcamalarında saydamlığın sağlanması ile mümkündür. Mali saydamlığın karar vermede ve kamu politikalarinin uygulanmasinda paydaşlar ve kamu sektörü arasındaki işbirliğini ifade eden katılımcllıkla birleşmesi ile hesap verebilirliğin ve hükümet performansının iyileştirilmesi amaçlanmaktadır. Bu doğrultuda gelişen katılımcı bütçe anlayışı, halkın bilgi ve belgelere ulaşmalarına, kararlara katılmalarnna ve değerlendirmelerine imkân sağlayacak vatandaş bütçelerinin oluşturulması, sosyal izleme araçlarının kullanılması ve sosyal izleme girişimleri gibi uygulamalarla hayata geçirilmektedir. Çalışma, katılımcı bütçe anlayışı çerçevesinde bu uygulamaları ve Türkiye'deki durumu ele almaktadır. Türkiye'de bilgi ve belgelerin kamuoyuna duyurulması anlamında bir mali saydamliğın varlığından söz etmek mümkünken; bütçenin katılımcı bir süreç içinde yapıldığını söylemek ise mümkün değildir.

Anahtar Kelimeler: Mali Saydamlık, Katılımcı Bütçeleme. 


\section{Evaluation of Participatory Budget Approach in Turkey}

Citation/O: Koç, Neslihan 2017). Evaluation of Participatory Budget Approach in Turkey, Hitit University Journal of Social Sciences Institute, Year 10, Issue 1, June 2017, pp. 443-470

Abstract: Plans, goals, expenses to be made and revenue to be collected related to fiscal policies are determined within the budget process. Assurance of the fiscal discipline, which is accepted as one of the important functions of the budget, is possible through enabling transparency in state government and public expenditures. Incorporation of financial transparency with participation, which means co-operation between stakeholders and public sector in decision making and implementation of public policies, aims to improve accountability and government performance. Participatory budget approach developing in this direction is actualised through practises such as formation of citizen budgets, which will enable the general public to be able to reach information and documents, participate in and evaluate the decisions, usage of social monitoring tools and social monitoring initiatives. This study addresses these practices within the framework of participatory budget approach and the status in Turkey. While it is possible to mention about a financial transparency in the meaning of public announcements of information and documents in Turkey; stating that the budget is constructed in a participatory process is not possible.

Keywords: Fiscal Transparency, Participatory Budgeting

\section{GÍRİ̧̧}

Tüm dünyada 1980 sonrası ve özellikle 1990’lı yıllardan itibaren kamusal borç yüklerindeki hızlı artış ile birlikte kamu kaynaklarının etkin kullanımına yönelik arayışlar ortaya çıkmıştır. Devlet kurumlarının, politikacı ve bürokratların kamu yararı yerine kendi çıkarları doğrultusunda yetki kullanmalarını önlemek amacıyla birçok denetim mekanizması oluşturulmuştur. Aşırı büyüyen bir devlet mekanizmasının kontrol altında tutulabilmesi ve daha da genişlemesinin engellenmesi için performansa dayalı uygulamalar öne çıkarken; mali disiplin, hesap verebilirlik ve saydamlık kavramları önemli hale gelmiştir. Seçmenlerin oyları karşılığında politikacıları, politikacıların bürokratları denetleyebilmesi için süreç, belge, uygulama ve sonuçlara ilişkin bilgilere ulaşabilmeleri ve sistemin de bu bilgiyi üretme ve yayınlama konusunda açık olması gerekmektedir.

Türkiye'de bu arayışlara yönelik en önemli düzenlemelerden biri 5018 Sayılı Kamu Mali Yönetimi ve Kontrol Kanunu'dur. Bu kanun doğrultusunda 
Performans Esaslı Bütçeleme uygulanmaya başlanmıştır. Bu doğrultuda bütçe hazırlama sürecinde Orta Vadeli Program, Orta Vadeli Mali Plan, idare stratejik planları, performans programları, faaliyet raporları gibi bütçeye ek birçok belgenin hazırlanması sağlanmıştır. Kamuoyunun bilgilendirilmesi ve katılımla ilgili hususlar, yerel yönetimlerle ilgili yapılan düzenlemelerde de mevzuattaki yerini almıştır.

Çalışmada mali saydamlık ve saydamlığın sistem içindeki işlerliğinin arttırılmasına yönelik olarak katılımcı bütçe anlayışı ele alınacaktır. Bu anlayış doğrultusunda vatandaşların bütçeyi izlemelerine, değerlendirmelerine ve bütçedeki harcama ve finansman ile ilgili kararlara katılmalarına imkân sağlayabilecek uygulamalar incelenecektir.

Literatürde katılımcı bütçe anlayışı genellikle yerel yönetimler düzeyinde ele alınmaktadır. $\mathrm{Bu}$ çalışmada hem yerel hem de ulusal düzeyde katılımc1 bütçelemeye ilişkin durum ele alınarak Türkiye'deki bütçe ve katılım literatürüne katkı yapılması beklenmektedir.

\section{MALI SAYDAMLIK}

Mali saydamlik, mali politikalarla ilgili plan ve hedefler ile kamu harcamalarının kamuoyuna açık olmasıdır. $\mathrm{Bu}$ şekilde hükümet, vatandaşlar ve mali piyasalar, mali durumlarının bugünkü ve gelecekteki durumunu doğru şekilde değerlendirme imkânına kavuşurlar. Kamuoyunun bu değerlendirmeyi doğru yapabilmesi için hedeflerin, faaliyetlerin ve harcamaların açık olması gerektiği kadar anlaşılır olması da gerekmektedir. Seçmenlerin, belirli bir süre ile yetkilendirdiği hükümetlerin kaynakları etkin ve doğru şekilde kullanıp kullanmadığını değerlendirebilmeleri, mali saydamlı ile mümkün olabilir. Böylece kamu hizmetlerinin gerçekleştirilebilmesi için toplumun katlandığı mali yüklerin gereksiz ve keyfi şekilde israf edilmesi engellenebilir. Mali saydamlık, hesap verebilirlik ile doğrudan ilgilidir ve ancak demokratik bir katılım söz konusu ise anlamlıdır.

Devletin mali tutumunu anlamak, vatandaşların kararlara katılım düzeylerini de etkileyecektir. Seçmenlerin katlandıkları vergi yükleri ile kamu harcamalarının boyutunu doğru değerlendirememeleri, mali yanılsama olarak ifade edilmektedir. Bütçe açığının dolaylı finansmanı, kamu mal ve hizmetlerinin algılanan fiyatını düşürerek, bir başka deyişle mali yanılsama yaratarak, vergi mükelleflerinin kamusal mal ve hizmet 
talebini yükseltir ve kamu harcamalarının artmasına neden olur (Çavuşoğlu, 2008; 144).

Mali saydamlığın geniş boyutu, hükümet- bürokrasi- seçmenler- sivil toplum kuruluşları/ çıkar grupları- basın- özel kesim- özerk devlet kurumları arasındaki ilişkileri belirleyen etik kurallarla ilgilidir. Örneğin hükümetin seçim öncesi personel alımı kararı vermesi, hatta bu alımları liyakat ilkesini gözetmeksizin gerçekleştirmesi etik kurallara da mali saydamlığa da aykırıdır. Yine bütçede bir yük oluşturan muafiyet, istisna gibi vergi harcamalarının sosyal ve ekonomik amaçlar dişında politik amaçlar uğruna yönlendirilmesi de bu doğrultuda değerlendirilebilir. Kamusal etiğin dışına çı1kılması hem kamu hizmetlerinin kalitesini düşürecek hem de kaynakların optimum dağılımı amacından uzaklaşmayı getirecektir.

\section{A. Mali Saydamlık- Bütçe İlişkisi}

Yapılacak harcamalar ve toplanacak mali yükler, bütçe süreci içinde belirlenmektedir. Günümüzde artan devlet fonksiyonlarına bağlı olarak artan kamu harcamaları ve bütçe açıkları hemen hemen her ülkede görülmektedir. Dengeli bir büyüme, ekonomik istikrar ve konjonktürel risklere karşı direnç oluşturulabilmesi için mali disiplin, bütçenin önemli fonksiyonlarından biri olarak kabul edilmektedir. Çoğunlukla mali kurallara bağlanmış bir harcama politikasıyla mali disiplinin ve iyi yönetişimin sağlanabilmesinin temel şartlarından biri, devlet yönetiminde ve harcamalarında şeffaflığın sağlanmasıdır. Kamuoyunun makroekonomik politikaları ve tercihleri bilmesi ve devletin kredibilitesini güçlendirmesi sebebiyle şeffaflık, ulusal ve uluslararası sermaye piyasalarına erişimi kolaylaştırır. Ayrıca değişen ekonomik şartların belirlenebilmesi ile krizlerin sıklığını ve şiddetini azaltmada maliye politikasına yardımcı olur (European Public Sector Information, 2013; 5).

Mali saydamlığın sağlanamaması devletin sosyal adaletsizliği önleyen değil üreten bir birim olmasını sağlayacaktır. Devletin adaletle ilgili hiçbir görevi bulunmadığını kabul etsek bile en azından adaletsizliğe bizzat kendisinin sebep olmaması gerektiğini söylemek mümkündür. KİT zararları, sosyal güvenlik sistemi açıkları, genişletilmiş vergi muafiyet ve istisnaları, sorunlu ihaleler gibi bütçeye yük getiren uygulamaların sistemin işleyişini sekteye uğratmak dışında kamu harcamalarının finansmanında belirli kesimlere artan bir vergi yükü getireceği açıktır. Türkiye'de dolaylı vergi ağırlıklı bir finansman yapısının olduğu düşünüldüğünde bu durumda öncelikle alt gelir 
grubunun vergi yükü ağırlaşacaktır. Vergiler yükseltilemeyecekse borçlanma ya da emisyon gibi diğer araçlara da başvurulabilir. Ancak her durumda saydamlığın olmayışı borçların sürdürülememesi ya da ağır enflasyon gibi sonuçlara hazırlıklı olmayı gerektirir.

Bütçelerin mecliste oylanması, bütçe hakkı ve mali saydamlık açısından elzemdir. Her ne kadar TBMM onayından geçse de Maliye Bakanlığı'nın komisyona sunduğu bütçe tasarısı metninin Genel Kurul'da her yönüyle değerlendirildiğini ve buna göre kabul edildiğini söylemek zordur. Kesin Hesap görüşmelerinde de durum fazla değişmemektedir. Yine genel bütçe dışında farklı isimler altındaki bütçelerle gelir toplanması ve harcama yapılması saydamlığın gerçekleşmesini engelleyen en önemli unsurlardandır. Bütçe dişı fonlar, KİT ya da SGK bütçeleriyle bütçede birlik ilkesinin sarsılmasının en önemli dezavantajı, bazı harcamaların meclis denetiminden çıkarılması ve keyfileştirilmesidir. Bu alternatif bütçeler çoğaldıkça devletin gerçek mali durumunu anlamak ve değerlendirmek zorlaşmaktadır.

Saydamlık, kullanılan bütçe unsurları ile de bağlantılıdır. Tahakkuk esaslı muhasebe sistemi, analitik bütçe sınıflandırması, çok yıllı bütçeleme gibi kullanılan yöntemler, hem kurumlar hem de hizmetler için toplamda ayrılan ödenek miktarının, gelecek yıllar için hedeflenen harcamaların, harcamaların ekonomideki etkilerinin değerlendirilebilmesi ve özellikle uluslararası karşılaştırmalarda anlam ifade etmesi açısından daha şeffaf bir bütçe anlayışına hizmet etmektedir. Aynı şekilde bütçe yapılmadan önce hazırlanan raporlar, dünyadaki ve Türkiye'deki ekonomik durumu ve bu doğrultuda nasıl bir harcama ve finansman politikası izleneceğini ortaya koymak bakımından önemlidir. Fakat kitabına uygun olarak hazırlanan rakamsal veriler ile gerçek her zaman örtüşmeyebilir. Bu nedenle bütçenin hazırlanışından daha da önemlisi, sonuçlarının değerlendirilmesidir. Bu noktada saydamlığın en önemli sacayaklarından biri denetimdir.

Denetim, kurum içinde oluşturulan birimler ve kurum dişında TBMM ve Sayıştay tarafından gerçekleştirilmektedir. Denetimler, genellikle belirlenen çerçevenin aşılıp aşılmadığı ve kanuni usullere uyulup uyulmadığı ile ilgilidir; performans ölçümünü içermemektedir. Kurumlar, ulaşmak istedikleri performans hedeflerini ve performans kritelerini zaten kendileri belirlemektedir. Bu hedefler belirlenirken var olan kalkınma planları ya da orta vadeli planlar esas alınmaktadır ancak hedeflerin tutturulmamas1 durumunda ne olacağı net olarak belirlenmemiştir. $\mathrm{Bu}$ açıdan sunulan 
hizmet ve ödenen vergilerin gerçek muhatabı olan kamuoyunun duyduğu memnuniyet ölçüsünde bir performans değerlendirmesi yapması en sağlıklısıdır. Fakat bütçenin teknik bir belge olmasının da etkisiyle kamuoyu duyarsızlığı saydamlığın boyutlarını belirlemektedir. Bu durumda bütçedeki ve harcamalardaki gelişmeleri değerlendirerek halkı bilgilendiren devlet dışında bağımsız bütçe kurumlarının varlığı da saydamlığın sağlanabilmesi için gereklidir. Belirtildiği gibi saydamlık, sadece seçmenlerin doğru karar verebilmesi için değil mali piyasaların düzgün işleyebilmesi, yabanc1 yatırımcıların çekilebilmesi gibi ekonomik büyüme ile bağlantılı alanlar açısından da gereklidir.

\section{B. Mali Saydamlığın Geliştirilmesine Yönelik Uluslararası Çalışmalar}

Son yıllarda şeffaflık, yönetişimi güçlendirme yollarından biri olarak Açık Yönetim (Open Government) gündeminin ayrılmaz bir parçası haline gelmiştir. Açık Yönetim düşüncesiyle paydaşların bildirimleri ve fikirleriyle kamu sektörüne katkıda bulunması yoluyla şeffaflığın; karar vermede ve kamu politikalarının uygulanmasında paydaşlar ve kamu sektörü arasındaki işbirliğini katılımla birleştirerek hesap verebilirliğin ve hükümet performansının iyileştirilmesi amaçlanmaktadır (World Bank, 2016a: 1). Bütçe sürecinde sivil toplumun daha fazla katılımını gerektiren Açık Yönetim'in kamu harcama yönetimi üzerinde önemli etkileri vardır. Bu açıdan mali saydamlığın geliştirilmesine yönelik uygulamalara bakılması gereklidir.

Birçok uluslararası kuruluş, dünya çapında mali saydamlığın gelişmesi için rehberler yayınlamaktadır. Uluslararası Para Fonu (IMF), iyi yönetişime olan katkısı nedeniyle mali saydamlığın üye ülkelerde uygulanmasını teşvik etmektedir. IMF, üye ülkeler arasında mali gözetimi ve hesap verebilirliği güçlendirmek amacıyla mali şeffaflıkla ilgili kuralları içeren belgeler yayınlamaktadır. İlki 1998 yılında yayınlanan, 2007 yılında güncellenen politika ve hesap verebilirliği geliştirmek için 2014 yılında tekrar güncellenen belge, Yeni Mali Saydamlık Tüzüğü (New Fiscal Transparency Code) olarak yayınlanmıştır. Bu belgede etkili bir mali yönetim ve denetim için gerekli olan dört temel belirlenmiştir (IMF, 2014:4);

-Mali raporlama: Mali istatistikler ve hesaplar, hükümetin mali durumu ve performansı ile ilgili uygun, kapsamlı, zamanında ve güvenilir bilgi sunmalidir. 
-Mali tahmin ve bütçeleme: Hükümetin bütçe hedefleri ve politika niyetleriyle birlikte, kamu maliyesinin gelişimi ile ilgili kapsamlı, zamanında ve güvenilir öngörüler açık bir şekilde ifade edilmelidir.

-Mali risk analizi ve yönetimi: Kamu maliyesine yönelik risklerin açıklanmış, analiz edilmiş ve yönetilmiş olduğunun ve kamu sektörü genelinde mali karar vermenin etkin şekilde koordine edildiğinin güvencesi verilmelidir.

-Kaynak gelir yönetimi: Doğal kaynak bağışlarının mülkiyet, sözleşme, vergilendirme ve kullanımı için şeffaf bir çerçeve sağlanmalıdır. Kaynak zengini ülkelerin özel koşullarına ilk üç ilkenin adapte edilmesi gerekir.

Görüldüğü gibi mali saydamlığın temellerinden biri raporlamadır. Oluşturulan hedefler ile uygulama arasındaki bağın kurulabilmesi doğru bir raporlama ve uygulanacak muhasebe sistemiyle ilgilidir. Var olan mali yapının ve oluşabilecek risklerin önceden anlaşılabilmesi, kaynakların buna uygun şekilde yönlendirilmesi ve bu doğrultuda doğru tahminlerle bütçenin oluşturulması doğru, güvenilir ve sürekli işleyen bir veri mekanizmasıyla mümkün olabilir. Yapılan harcamaların ve izlenen usullerin takip edilebilmesindeki önemli unsurlardan biri, teknik/bilişsel altyapıdır. Verilerin elde edilmesi, sistemli ve güvenilir şekilde analiz edilebilmesi ve raporlama ayağının işleyebilmesi için teknolojik uyarlamaların yapılması ve e-devlet sisteminin yaygınlaştırılması gerekmektedir.

OECD tarafından hazırlanan Bütçe Şeffaflığı İçin En İyi Uygulamalar (Best Practices for Budget Transparency), hükümetlerin kendi ülkelerindeki bütçe şeffaflık derecesini arttırmaları için bir referans aracı olarak tasarlanmıştır. Bütçe şeffaflı̆̆1, zamanında ve sistematik bir şekilde ilgili tüm mali bilgilerin tam olarak açıklanması olarak tanımlanmaktadır.

En İyi Uygulamalar, üç bölümden oluşmaktadır. Birinci bölümde hükümetlerin hazırlamaları gereken temel bütçe raporları ve raporların genel içerikleri listelenmiştir. İkinci bölümde raporlara dâhil edilecek mali ve mali olmayan performans bilgilerini içeren özel açıklamalar yer almaktadır. Üçüncü bölümde raporların kalitesi ve bütünlüğünü sağlamak üzere gerçekleşmiş uygulamalar, farklı ülke deneyimlerine dayanılarak aktarılmaktadır. En İyi Uygulamalar, 2015'ten bu yana, bütçe hazırlama, yönetim ve iyi yönetissimin diğer yönleri ile bağlantılı kapsamlı ve entegre bir rehberi sağlayacak Bütçesel Yönetişim Üzerine Tavsiyeler (The 
Recommendation on Budgetary Governance) ile somutlaştırılmış ve güncellenmiştir (OECD, 2015).

Uluslararası Bütçe Ortaklığı (The International Budget Partnership), yoksulluğu azaltmak ve yönetişim kalitesini artırmak amacıyla kamu bütçelerini etkilemek ve analiz etmek için sivil toplum ile işbirliği yapmaktadır. Açık Bütçe Anketi 2012 (The Open Budget Survey) ile hükümetlerin kamu finansmanlarını nasıl yönettiklerini ölçmek amacıyla dünyanın dört bir yanındaki yüz ülke, bütçe şeffaflığı, denetimi ve bütçeye katılım açılarından incelenmiştir. Türkiye'nin skoru 50 olarak ölçülmüştür ve bütçe harcamaları konusunda halka "bazı" bilgileri veren ülkeler kategorisinde yer almaktadır (IBP, 2015). Yüz ülkenin ortalama puanın 43 olduğu göz önüne alınırsa Türkiye, ortalamanın üzerinde bir puana sahiptir. Ancak Türkiye açısından sonuçlar, 2006'da 42, 2008'de 43, 2010'da 57 olarak ölçülmüştür (IBP, 2015). Buna göre 2012 yılında 2010 yılına göre bir gerileme yaşanmıştır.

Açık Bütçe Endeksinde sekiz temel bütçe dokümanının yayınlanıp yayınlanmadığına göre değerlendirme yapılmaktadır. Bunlar, bütçe öncesi raporu, hükümetin bütçe teklifi, merkezi hükümet bütçesi, vatandaş bütçesi, yıl içi raporlar, yarıyıl raporu, yılsonu raporu, denetim raporudur (TESEV, 2012). Endekste belirtilen raporların Türkiye'deki uygulama karş1lıkları Tablo-1'de yer almaktadır.

Tablo-1: Açık Bütçe Endeksinde Yer Alan Raporların Türkiye'deki İsimleri

\begin{tabular}{|l|l|}
\hline Bütçe Öncesi Raporu & Orta Vadeli Mali Plan \\
\hline Hükümetin Bütçe Teklifi, & $\begin{array}{l}\text { Merkezi Yönetim Bütçe Kanun } \\
\text { Tasarısı }\end{array}$ \\
\hline Merkezi Hükümet Bütçesi & Merkezi Yönetim Bütçe Kanunu \\
\hline Vatandaş Bütçesi & Üretilmiyor \\
\hline Y1l İçi Raporlar & Aylık Bütçe Gerçekleşme Raporları \\
\hline Yarıyıl Raporu & Yarıyıl Raporu (Yayınlanmıor) \\
\hline Y1lsonu Raporu & Genel Faaliyet Raporu \\
\hline Denetim Raporu & Genel Uygunluk Bildirimi \\
\hline
\end{tabular}

Kaynak: TESEV, 2012. 
Türkiye'de bu belgelerden yarıyıl raporu ${ }^{1}$ üretilmiş ancak yayınlanmamış; vatandaş bütçesi ise üretilmemiştir.

\section{KATILIMCI BÜTÇE ANLAYIŞI}

Katılımcı bütçe, aktif vatandaşlığ1, sosyal öğrenmeyi, sosyal hesap verebilirliği ve sosyal izleme girişimlerini destekleyerek temsili yönetimin eksik unsurlarını tamamlayan bir doğrudan katılım mekanizmasıdır.

Dünya Bankası'na göre kamusal bütçe karar alma sürecine vatandaşların katılımını amaçlayan yenilikçi bir mekanizma olarak katılımcı bütçe, kamu önceliklerinin bildirimine olanak verdiği için kaynak dağılımının daha kapsayıcı ve adil olmasına vesile olabilir (World Bank, 2016b). Mali politika ve kamu harcama yönetiminde şeffaflı̆̆ı, vatandaşların devlete güvenini ve dolayısıyla hükümetlerin güvenilirliğini arttırma; patronaj ilişkilerini, belirli zümrelerin hâkimiyet kurmasını ve yolsuzluğu azaltma potansiyeli ile katılımcı bütçe, ihtiyaçların tanımlanmasını, yatırımların planlanmasını, vergi sistemleri ile proje yönetimi arasında bağlantı kurulmasını sağlar. Bu da hizmet sunumunda iyileşme anlamına gelecektir (World Bank, 2016b).

Katılımcılığın ilk aşaması olan bilgilendirme, devletin tek taraflı olarak gelecekteki hizmetlerini, bu hizmetler için yapacağı harcamaları, finansmanı ve borçlanmayı bildirdiği bir süreçtir. İkinci aşama, danışmadır. Danışma, devletin geri besleme yoluyla halkın memnuniyet, görüş ya da önerilerinin alındığı karşılıklı bir ilişkiyi ifade eder. Katılımcılığın son aşaması olan aktif katılım ise halkın politika oluşturma sürecinde doğrudan rol almasıdır (Ergen, 2012: 320). Mali saydamlığın tam olarak gerçekleşmesini sağlayacak bir katılımcılıktan söz edebilmek için bu üç aşamanın bir arada olması gerektiği söylenebilir.

Vatandaşların kısa süreli ve görünür fayda sağlayabilecekleri alanlardaki kamu harcamalarına sıcak bakarken; uzun vadeli ve sunulması hayati kamu hizmetlerine uzak durmaları mümkündür. Harcamaların verimsiz alanlarda israf edildiğini ya da kendisinin yeterince temsil edilmediğini düşünen bireylerin vergi artışları ya da harcama payları ile ilgili itirazları ise daha yüksek olacaktır. Daha sorumlu maliye politikalarının uygulanabilmesi için kendini devlete bağlı ve sorumlu hisseden ve kamu politikalarıyla ilgili daha fazla fikir sahibi olan kişilerden oluşan bir vatandaş katılımı önemlidir.

1 Bir bütçe yılının ortasında, bütçenin etkilerini gözden geçiren ve bütçe oluşturulurken ele alınan ekonomik varsayımlardaki değişimleri ele alan belgedir. 
Katılım, vatandaşların devlete daha çok güven duymalarını sağlayacak bir mekanizma olarak düşünülebilir. Kişilerin daha hayati kamusal hizmetler yerine kısa vadeli yararları öncelemeleri durumu, kişilerin bütçe ve özellikle harcanmalarla ilgili daha bilinçli hale gelmesi, devleti sahiplenme derecelerinin ve devlete ve topluma karş1 sorumluluk duygularının artması ölçüsünde daha rasyonel seçimler gerçekleştirmelerinin sağlanması ile aşılabilir. Sadece belirli kesimlerin değil toplumun her kesiminin dengeli katılımı sağlanabilirse elde edilmeyi umulan çıkarlar karşılıklı olarak dengelenecektir. Böylece daha adil bir toplumsal dağılım için daha kapsayıc1 bir katılım mekanizması kurulması gerektiği de kendiliğinden ortaya çıkmaktadır.

Katılımcı bir bütçe anlayışında öncelikle kimlerin, nasıl ve hangi aşamada katılımlarının sağlanması gerektiği değerlendirilmeli, buna uygun hukuki düzenlemeler yapılmalı ve katılımcılığı destekleyen mekanizmalar sisteme entegre edilmelidir. Katılım süreçleri açık ve takip edilebilir olmalı ve sonuçlar raporlanarak vatandaşlara duyurulmalıdır. Bu açıdan vatandaş bütçelerinin yapılması, sosyal izleme araçlarının kullanılması, sosyal izleme girişimlerinin oluşturulması hem katılımcılığı hem de mali saydamlığı geliştirebilecek uygulamalardandır.

\section{A. Katılımcı Bütçe Anlayışını Destekleyen Uygulamalar}

Katılımc1 bütçeleme, vatandaşlara gerekli bilgilendirmelerin, görüş alışverişlerinin yapıldığı, politika oluşturma süreçlerine katılma şansının verildiği bir anlayıştır. Yerel yönetim düzeyinde uygulanma imkânının daha kolay olduğu düşünülebilirse de halkın, yasama, yürütme ve denetim kurumlarının daha etkin şekilde sistemdeki rollerini yerine getirmeleriyle ulusal düzeyde de katılımcı bütçelemenin hayata geçirilmesi mümkündür. Katılım ve saydamlık düzeyi açısından gelişmiş ülkelerdeki seviyenin yakalanması öncelikli hedef olarak belirlenirse bu ülkelerdeki kurumların, iyi uygulama ve proje örneklerinin yakından izlenmesi faydalı olacaktır.

\section{Vatandaş Bütçesinin Hazırlanması}

Sivil toplum politikası analizleri, alternatif bütçe hazırlanması suretiyle genellikle belirli grupları etkileyen konular üzerinde yoğunlaşır; örneğin birçok ülkede cinsiyet dayalı bütçeler ve çocuk bütçeleri geliştirilmiştir. Yaş, engellilik, ırk-etnik kimlik ve bölgesellik perspektiflerini içeren diğer bütçeler de oluşturulabilir (World Bank, 2016a: 8). Yayınlanan bütçe rakamları 
doğrultusunda dezavantajlı olarak değerlendirilebilecek gruplara yönelik harcama tutarlarının ayrıştırılması suretiyle sosyal bütçeler izlenebilir. Bu bütçelerin hazırlanması, temelde belirli toplumsal gruplara yönelik faaliyetlerin ayrıştırılarak anlaşılması ve varsa eksikliklerin tespit edilmesi amacindadir.

Vatandaş bütçesi de dar anlamda teknik detayların sadeleştirilmesi suretiyle harcama ve gelir planlarının halk tarafından anlaşılmasını mümkün kılan bir belgedir. Bütçe verilerinin sosyal, ekonomik ve mali etkileriyle ilgili tahmin ve beklentilerin halka ulaştırılmasını sağlar.

Ülkenin şartlarına ve kapasitesine bağlı olarak özellikle federal devletlerde veya yerel yönetimlerin hizmet sunumunda önemli rol oynadığı ülkelerde bu birimlere yapılan transferlere ve mali ilişkilere vatandaş bütçelerinde yeterince yer verilememektedir. Oysa kamuoyu bu bölgelere ya da yerel yönetimlere ne kadar transferde bulunulduğunu, gelirlerin bu birimler arasında hangi formüle göre dağıtıldığını ve harcama dağılımını özellikle bilmek isteyebilir. Aynı şekilde yerel yönetimler tarafindan yapılan kamu yatırımlarıyla ilgili detaylı bilgi verilmesi istenebilir (IBP, 2016b: 20). Nas1l hazırlanacağına dair standart bir uygulama olmamakla birlikte vatandaş bütçelerinin öncelikle ülkeye özgü koşullara uygun şekilde hazırlanması gerekmektedir. Bunun yanında Petrie\& Shields (2010: 8), vatandaş bütçeleri için standart bir içindekiler taslağı önermişlerdir. Tablo-2'de bu taslak yer almaktadir.

Tablo- 2: Vatandaş Bütçesi Bölümleri

\begin{tabular}{|c|c|}
\hline $\begin{array}{l}\text { 1.Bölüm: } \\
\text { Giriş }\end{array}$ & $\begin{array}{l}\text { Hükümetin kılavuzu yayınlamaktaki amaçları; kamu } \\
\text { maliyesi mevzuatında yıllık bütçenin yeri; bütçe } \\
\text { süreci ve bütçenin kurumsal kapsamı hakkında çok } \\
\text { k1sa bir açıklama. }\end{array}$ \\
\hline $\begin{array}{l}\text { 2.Bölüm: } \\
\text { Ekonomik } \\
\text { Görünüm } \\
\text { Hükümet } \\
\text { Hedefleri }\end{array}$ & $\begin{array}{l}\text { Makroekonomik tahminler ve bütçenin temelindeki } \\
\text { makroekonomik varsayımlar; temel ekonomik } \\
\text { varsayım varyasyonlarının toplam mali göstergelere } \\
\text { duyarlılığı; hükümetin ulusal kalkınma stratejisi ve } \\
\text { orta vadeli maliye politikası hedefleri. }\end{array}$ \\
\hline $\begin{array}{l}\text { 3.Bölüm: } \\
\text { Devlet } \\
\text { Muhasebesi ve } \\
\text { Bütçe Beklentileri }\end{array}$ & $\begin{array}{l}\text { Toplam gelirler, harcamalar, harcama ve gelir } \\
\text { kaynaklarının tahsisini içeren orta vadeli mali denge } \\
\text { ve önceki yıl rakamlarıla karşlaştırmalar; kamu } \\
\text { borcu, mali riskler ve mevcut politika ve eğilimlerin } \\
\text { sürdürülebilirliği. }\end{array}$ \\
\hline $\begin{array}{l}\text { 4.Bölüm: } \\
\text { Yeni Önleml }\end{array}$ & $\begin{array}{l}\text { Temel bütçe girişimlerin özeti; bunların yoksullar, } \\
\text { kadınlar ve dezavantajlı kesimler gibi kilit toplumsal } \\
\text { gruplar üzerindeki mali etkilerinin tahmin edilmesi; }\end{array}$ \\
\hline
\end{tabular}




\begin{tabular}{|c|c|}
\hline & $\begin{array}{l}\text { bunların hükümetin belirtilen politika hedeflerini } \\
\text { karş1lamadaki katkıs1. }\end{array}$ \\
\hline $\begin{array}{l}\text { 5.Bölüm: } \\
\text { Hizmet } \\
\text { Sunumunun } \\
\text { Geliştirilmesi }\end{array}$ & 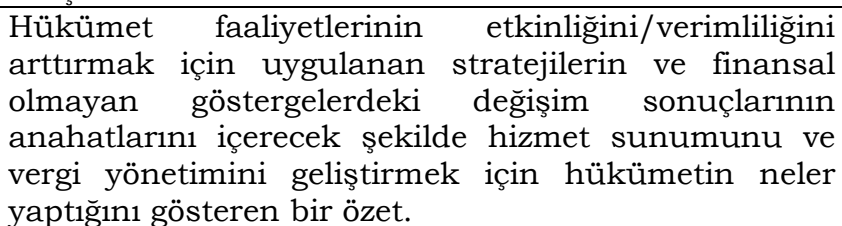 \\
\hline
\end{tabular}

Kaynak: Petrie M.\& Shields,J., 2010:8.

Bütçenin analizi, bütçeden yatırımlar için ne kadar pay ayrıldığı, bu yatırımların hangi sektör veya bölgelerde yoğunlaştığını, yardım faaliyetleri kapsamında ne kadar transfer ödemesi yapıldığını, hangi kesimlerin yapılan harcamalardan en çok fayda elde ettiği gibi harcama bilgilerine ve makroekonomik değerlendirmelere ulaşılmasını sağlar. Hatta vatandaş bütçelerinin yayınlanmasıyla sivil toplum kuruluşları, ülkenin bütçesi ve önceliklerinin neler olduğu, vatandaş bütçesinde yer verilmeyen bilgilerin ve eksikliklerin neler olduğu gibi soruları yanıtlayan vatandaş bütçelerini analiz eden raporlar hazırlayabilirler (IBP, 2016a: 13).

Mali sistemin iyileştirilmesi ve daha açık hale getirilmesini sağlayacak bu belgenin hazırlanması için öncelikle yönetim sisteminin odağında devletin değil vatandaşın olması gerektiğinin hatırlanması ve vatandaşın hangi kamu hizmetleri ve kamu hizmetlerinde hangi kriterleri görmek istediğinin anlaşılması gerekir. Bu açıdan bilgilendirilme dışında vatandaşların bütçe kararlarında etkili olabilmesi, vatandaş bütçeleri için temel bir gereksinimdir. İster açık toplantılarla ister internet üzerinden yapılan oylamalarla vatandaşların ödedikleri vergilerin kendileri için öncelikli projelerde kullanılmasının sağlanması ve israfa yol açtığ1 düşünülen hizmetlerin elenmesi mümkün olacaktır.

\section{Sosyal İzleme Araçlarının Kullanılması}

Sosyal izleme (social monitoring), vatandaşların, hizmetten yararlanan kişilerin veya sivil toplum kuruluşlarının kamusal işler ve hizmet sunumunun etkileri ve süreçlerinin gözlenmesine dâhil olmaları anlamına gelir. Sosyal izleme aracılığıyla sivil katılımın gerçekleşebileceği alanlardan bazıları, bütçeleme, politika geliştirme, merkezi ya da yerel kamusal hizmet sunumu ve planlaması ile yoksullukla mücadeledir. 
Sosyal izleme için kullanılabilecek araçlar, Vatandaş Karneleri (Citizen Report Cards- CRC), Topluluk Puanlama Karneleri (Community Score CardsCSC), Sosyal Denetim (Social Audits), Katılımc1 Harcama Takibi (Participatory Expenditure Tracking), Vatandaş Sözleşmeleri (Citizen's Charters), İhale İzleme (Procurement Monitoring) olarak sayılabilir (LopezAcevedo, Krause\& Mackay 2012: 89).

$\mathrm{Bu}$ tarz özel düzenlemeler dışında bilgi edinme hakkı (ve bu hakkın yasalaşmış olması), danışma kurulları ve kamuya açık oturumlar da sosyal hesap verebilirlik çerçevesinde toplumun yönetişim sürecine katılımını destekleyen uygulamalardır.

Bu bölümde, sosyal izleme araçları içinde uygulama alanı daha fazla olan Vatandaş Karneleri, Topluluk Puanlama Karneleri ve Sosyal Denetim ele alınacaktır.

\subsection{Vatandaş Karneleri}

Vatandaş Karneleri, bir kamu hizmetinden yararlanan vatandaşların geri bildirimlerini anketler yoluyla toplayarak hizmet sağlayıcıların performanslarını tekil olarak değerlendirmeyi veya hizmet sağlayıcılar arasında performans karşılaştırması yapmayı ve geri bildirimlerden bir veri seti oluşturmayı sağlayan bir araçtır. Vatandaş Karneleri kullanılarak özellikle varsa belirli bölgeler ya da demografik gruplara yönelik hizmet sunumundaki eksiklikler belirlenebilir. Böylece hizmet sunumunun iyileştirilmesi ve zaman içinde hizmet kalitesindeki değişimler izlenebilir. Hindistan'in Bangalore Kenti'nde başlayan uygulama bugün Kolombiya, Ukrayna, Peru ve birçok Asya ve Afrika ülkelerinde kullanılmaktadır (Asian Development Bank, 2007: 4). Bangalore'de 1994 ve 1999 yıllarında hükümet dışı bir kuruluş olan Halkla İlişkiler Merkezi'nin yaptığı anketlerde sorulan hizmetlerden duyulan memnuniyetin toplamda \% 9'dan \%34'e yükseldiği görülmüştür (Lopez-Acevedo, Krause\& Mackay, 2012: 94).

\subsection{Topluluk Puanlama Karneleri}

Topluluk Puanlama Karneleri, toplumun yerel ve hükümetlerin idari birimlerinin hizmet ve projelerinin izlenmesi ve performans değerlendirmelerinin yapılması amacıyla kullanılan nitel izleme araçlarıdır. Sosyal denetim, sosyal izleme ve vatandaş karneleri uygulamalarının bir karışımıdır. Vatandaş karnelerinde olduğu gibi Topluluk Puanlama Karneleri süreci, hizmeti sunanların sosyal ve kamusal hesap verebilirliklerini ve 
sorumluluklarını gerektiren bir araçtır. Vatandaş karnelerinde bilgilerin toplanmasi anketler yoluyla, topluluk puanlama karnelerinde ise odak grup tartışmaları aracılığıyla gerçekleşmektedir. Hizmeti sunanlar ile toplum arasında anında geribildirim sağlayan bir ara yüz görüşmesini içeren süreç çok uzun değildir hatta tek bir toplantıda tamamlanabilir (World Bank, 2016c: 1).

Uygulamanın amac1, sadece bir puan kartı üretmek değil belgelenmiş algıları ve bazı hizmetlerle ilgili geribildirimleri kullanarak bu hizmetlerin işleyişinde gerçek bir iyileşme meydana getirmektir (World Bank, 2016c: 1). Bilgi sağlanması bu belgelerin bir parçası olmakla birlikte daha da önemlisi anahtar paydaşların kimler olduğu ve hizmet sunum sorunlarını çözmek için ortak eylem planları hazırlamak ve bu planları takip etmek için onları bir araya getiren bir süreç olmasıdır. Topluluk Puanlama Karnelerinin işbirliğine açık alanlar ile arz ve talep tarafındaki aktörlerin kolektif sorun çözme biçimlerini kolaylaştırdığı alanlarda en iyi uygulama sonuçlarına ulaşıldığı görülmektedir (Wild\& Harris, 2011:5).

$\mathrm{Az}$ gelişmiş ülkeler açısından hizmet kalitesinin iyileştirilmesi daha önemli iken gelişmiş ülkeler açısından bu belgeler, ayrıca hizmetlerin yaşam kalitesine etkisini değerlendirmede de bir performans göstergesi olarak kullanılabilir. Kamu tarafından sunulan hizmetlerin sağlık ve refah, sosyal etkileşimler, çevresel kalite, kamu, özel ve gönüllü organizasyonlardaki personelin çalışma kalitesi gibi alanları içeren yaşam kalitesine katkısı, yönetimin başarısının değerlendirilmesi ve geliştirilmesi açısından önemlidir (Bovaird, Loeffler\& Martin, 2003: 1048).

Hizmet sunumu vatandaşlar için önemli olduğuna göre yerel yönetişim süreçlerinin kalitesi de önemlidir. Bu açıdan hizmetlerin kalitesi ile yöneticilere duyulan güven ve siyasi partiler ve sivil toplum kuruluşları içindeki katılım seviyesi arasında doğru orantı olduğuna göre Topluluk Puanlama Karnelerinin tüm bu göstergeleri kapsayacak şekilde oluşturulması gerekmektedir.

\subsection{Sosyal Denetim}

Sosyal denetim, devlet birimlerinin finansal olmayan faaliyetlerini planlamalarını, yönetmelerini, değerlendirmelerini ve sosyal ve ticari faaliyetlerinin kurum içi ve topluma yönelik sonuçlarını izleyebilmelerini sağlayan bir araçtır. Yönetimin sosyal denetimi, idari sistem ve onun iç 
dinamiklerinin toplumdaki geniş çoğunluk açısından ne anlama geldiğini kavramak anlamına gelmektedir.

Sosyal denetleme, bir organizasyonun sosyal ekonomik ve çevresel yararlarının belirlenmesini ve paydaşlarının görüşlerine dayalı olarak sistematik ve düzenli izleme yoluyla finansal olmayan hedeflerine ulaşılmasıyla ilgili performansının değerlendirilmesini sağlayan bir süreçtir. Organizasyon düzeyinde sosyal denetim, sosyal muhasebe hesaplar1 kullanılarak kurum içinde, sosyal denetçi tarafından yapılan diş denetim yoluyla gerçekleştirilir. Topluluk düzeydeki sosyal denetim ise toplumsal değerler, sosyal fayda, sosyal sermaye ve yürütülen program ya da faaliyeti yürüten birimin kişilerle olan etkileşiminin kalitesi ile ilgili bilgiler, anketler, yüz yüze mülakatlar, grup çalışmaları yoluyla toplanır. (CGG, 2005:9-29)

Sosyal denetim, sivil toplum kuruluşları, özel firmalar, yerel yönetimler ve diğer devlet kurumlarının yürüttükleri faaliyetlerin reel faydalarını analiz etmek ve kendilerinin toplumda nasıl bir etki yarattıklarını anlamaları için kullanılabilecekleri bir araçtır. Olumlu katkılarından biri sosyal refahın geliştirilmesi olan sosyal denetim sayesinde devlet- sivil toplum, şirketmüşteriler, sivil toplum kuruluşu-gönüllüler arasındaki güvenin ve bu kuruluşların meşruiyetlerinin güçlendirilmesi mümkündür.

\section{Sosyal İzleme Girişimlerinin Oluşturulması}

Ülkeler, harcama, vergileme ya da borçlanma kararları üzerinde çeşitli sınırlar belirleyerek mali disiplini sağlamak adına bağlayıcı kurallar koyabilmektedir. Mali kurallar olarak adlandirılan bu uygulamalar, temelde hükümetlerin popülist taleplere karşı durabilmeleri ve özellikle aşırı borçlanmayı engelleyebilmek için geliştirilmiştir. Ancak her ülkede istenen sonucu yeterince sağlamayabilmektedir. Avrupa Birliği Maastrich Kriterleri'ne rağmen borçluluk düzeyinin yüksek olduğu İspanya, Yunanistan, Portekiz gibi ülkeler bu durumun kanıtı olarak gösterilebilir. Bu nedenle mali kuralların yanı sıra mali konseyler oluşturulması gündeme gelmiştir. Örneğin 2010 tarihinden beri faaliyet gösteren Bütçe Sorumluluk Ofisi (The Office for Budget Responsibility- OBR), İngiltere'de kamu maliyesi analizlerini gerçekleştiren bağımsız bir gözlem kuruluşudur. Ofis, yılda iki kez yaptığı ekonomi ve kamu maliyesine ilişkin tahminleri ile hükümetin mali hedeflerini karşılaştırarak hükümetin performansını değerlendirmektedir. 
Mali konseyler, hükümet tarafından finanse edilse de Merkez Bankası'nın tarafsızlığı esas alınarak kurulmuş, bağımsız ve bütçenin hazırlanışı, uygulanış1, tahminlerin tutarlılığ ve mali performans gibi alanlarda hükümetle ilgili gözlemlerini halkın bilgisine sunan kurumlardır. Çeşitli ülke uygulamalarına göre mali kural uygulamalarının tamamlayıcısı olan bu kurumlar, doğrudan hükümete veya parlamentoya bağlı olabilmektedir (Kovanc1lar\& Uğur, 2011: 106).

Sosyal izleme sürecinde, analiz ve önerileriyle politika oluşumuna katkıda bulunan sivil toplum örgütleri, analiz sonucu ulaştıkları bulguları, medya aracılığıyla duyurmak ve lobi oluşturmada kullanmak konusunda oldukça başarılıdır. Devlet öncülüğünde oluşturulmamış olsa dahi ulusal, bölgesel ya da yerel düzeyde sivil toplum öncülüğünde faaliyet gösteren ve sosyal izleme girişimleri olarak adlandırılabilecek bu tür kuruluşlar, kamu hizmetlerinin kalitesinin ve etkinliğinin denetlenmesi ve kaynakların belirlenen amaçlar doğrultusunda kullanılıp kullanılmadı̆̆ının değerlendirilmesinde etkin rol oynayabilirler. Bu noktada şu konunun altı çizilmelidir; sosyal izleme sürecinin başarılı olabilmesi, gerçekçi ve doğru analizlerin yapılabilmesine; bu ise, doğru verilere ulaşılabilmesine bağlıdır. Bu anlamda kurumların devletten bağımsız ve onunla işbirliği içinde olmasının önemi büyüktür. Mali konseylerin kurulması faydalıdır ancak kurulmamış ise de aynı görevi yerine getiren sivil toplum örgütlerinin doğru verilere erişim başta olmak üzere hareket serbestliklerinin sağlanması gerekmektedir.

\section{TÜRKIYYE'DE KATILIMCI BÜTÇELEME}

Bütçe şeffaflığının ve katılımcılığın sağlanmasıyla ilgili yayınlanması gereken belgelerden birinin vatandaş bütçesi olduğundan bahsedilmişti. Yine sosyal izleme araçlarının kullanılması ve sosyal izleme girişimlerinin oluşturulması, katılımcı bütçe anlayışının uygulama araçları olarak ele alınmıştı. İlerleyen bölümde bunların Türkiye'deki yansımaları ve daha sonra yerel ve ulusal düzeydeki katılımcı bütçe uygulamaları ele alınacaktır.

\section{A. Katılımcı Bütçe Anlayışını Destekleyen Uygulamalar Açısından Durum}

Türkiye'de mali saydamlığı arttırmaya yönelik olarak fon sayısının azaltılması, Kamu Finansmanı ve Borç Yönetimi Kanunu ve Kamu Mali Yönetimi ve Kontrol Kanunu'nun kabul edilmesi gibi uygulamalara gidilmiştir. Belirtilen kanunlarla harcama ve borçlanmalara sınırlamalar 
getirilmiş, bütçe sürecinde kamuoyuna bilgi verilmesiyle ilgili düzenlemeler yapilmıştır.

Türkiye'de Mart 2016'da Maliye Bakanlığı tarafından İtalya ile ortak yürütülecek "Genel Yönetim Mali İstatistiklerinin Sunumuna ve Kullanımına İlişkin Kapasitenin Geliştirilmesi” AB Projesi ile halkın etkin bir şekilde bütçe sürecine dâhil edilmesini sağlayacak ve halka hitap eden bilgilerin yer alacağı Avrupa standartlarında bir vatandaş bütçesi anlayışının geliştirileceği duyurulmuştur. Ancak vatandaş bütçesi benzeri bir belge henüz yayınlanmamıştır.

Türkiye'de yapılan kurum içi ve Sayıştay'ın yaptığı kurum dışı denetimler genellikle harcamaların bütçede verilen ödeneklere uygun olup olmadığına yani usule ilişkindir. Katılımc1 bir bütçenin enstrümanlarından olan vatandaş karnelerinin yapılan harcamaların usulüne uygunluğundan çok etkin ve kaliteli bir hizmet sunumunu sağlayıp sağlamadığını anlamak için önemli olduğu belirtilmişti. Bu anlamda özellikle vatandaşları doğrudan ilgilendiren eğitim, güvenlik ve sağlık gibi hizmetler ile şehir içi ulaşım, su ve katı atık hizmetleri gibi yerel hizmetlerde vatandaş karneleri uygulamasına gidilmesi, etkili sonuçların alınması aynı zamanda bölgelerarası karşılaştırmaların yapılması mümkün olacaktır. Ancak Türkiye'de Vatandaş Karneleri gibi Topluluk Puanlama Karneleri, Sosyal Denetim, Katılımc1 Harcama Takibi, Vatandaş Sözleşmeleri, İhale İzleme gibi diğer sosyal izleme araçları da kullanılmamaktadır. Sadece TÜİK tarafından her yıl yapılan Yaşam Memnuniyet Araştırmaları, Vatandaş Karneleri kategorisinde değerlendirilebilir. Yaşam Memnuniyeti Araştırması, bireylerin genel mutluluk algısını, toplumsal değer yargılarını, temel yaşam alanlarındaki genel memnuniyetini ve kamu hizmetlerinden memnuniyetini ölçmek, memnuniyet düzeylerinin zaman içindeki değişimini takip etmek amacıyla, 2003 yılından itibaren düzenli olarak gerçekleştirilmektedir. Buradaki sonuçlardan vatandaşların hem yerel hem ulusal hizmet alanlarındaki düşüncelerini yıllar bazında takip etmek mümkündür. Ancak çıkan sonuçlara yönelik bir politika gerçekleştirilmesi zorunluluğu yoktur. Araştırmanın anketler yoluyla yapılması açısından Vatandaş Karneleri uygulamasına benzemekte; devlete bağlı bir kuruluş tarafından yapılması açısından ise ayrılmaktadır.

Türkiye'de TEPAV, TESEV, SETA gibi ekonomik, politik ve sosyal alanlarda araştırmalar yapan, raporlar yayınlayan ve sosyal izleme sürecine dahil olan 
sivil toplum kuruluşları bulunmaktadır. Fakat bu kuruluşların çalışmalarının akademik ve bürokratik olarak sınırlı bir kesime hitap ettiği ve etkilerinin de çok sınırlı olduğu söylenebilir. Harcamalar, harcamaların finansmanı ve borçlanma ayakları bulunan bütçenin tartış1labilmesi, ilgili topluluğun genişlemesi ve belgelerin anlaşılabilir olmasına bağlıdır.

Mali kurallar açısından bir değerlendirme yapmamız gerekirse, mali kural sayılabilecek düzenlemeleri mevzuatta bulmak mümkündür. Türkiye'de 5018 say1l kanunla getirilen mali kurallar; orta vadeli harcama sistemi, harcama kısıt1, ödenek aktarma kısıtı, yedek ödenek kısıtı, örtülü ödenek kısıtı, ertesi yıla geçen yüklenme kısıtı, bütçe dışı avans kısıtı ve ödenek üstü harcama yapılmasına müeyyide getirilmesi olarak sayılabilir.

Yine 5393 sayılı Belediye Kanunda yer alan belediyelerin dış borçlanması ve tahvil ihracının sadece yatırım programında yer alan projelerle sınırlandırılması, iç borçlanmaya karar verme yetkisinin, bir önceki kesinleşmiş bütçe gelirine bağlanması, belediyenin yıllık toplam personel giderlerinin, gerçekleşen en son y1l bütçe gelirlerinin \%30'unu (nüfusu 10.000'in altında olan belediyelerde \%40'n1) aşamayacağı kuralları mali disiplinin sağlanması, harcama ve borçlanmanın sınırlanmasına yönelik düzenlemelerdir. Ancak mali kuralları düzenleyen ayrıca bir kanun çıkarılmamıştır. Yine pek çok ülkede kamu mali kesimini kontrol altına alabilmek için mali kuralların yanı sıra varlıklarını sürdüren bağımsız bir mali konsey de oluşturulmamıştır.

\section{B. Yerel Yönetimler Düzeyinde Katılımcı Bütçeleme}

Yeni kamu yönetimi anlayışı doğrultusunda gündeme gelen yönetişim kavramı, merkezi yönetim dışında yerel yönetimler, özel ve mesleki kuruluşlarla birlikte halkın ve sivil toplum kuruluşlarının politika belirleme ve uygulamada aktif hale gelmesi gerekliliğini ifade etmektedir. Bu noktada yapılan bütçenin kamuoyu ile yalnızca paylaşılmasının önemli ancak yeterli olmadığ1 görülmektedir. Örneğin ABD'de yürütme tarafından sunulan bütçe üzerinde kamuya açık oturumlar düzenlenir. Yapılan ön sunum neticesinde kamuoyunun eleştirileri doğrultusunda bütçe üzerinde değişiklik yapılması teknik olarak mümkünken bu sunumdan önce alternatifler ayıklanmış ve önemli politika tercihleri çoktan yapılmış olduğundan yapılan bu ön bilgilendirme dahi yetersiz kabul edilmektedir. Bunun için ABD'de yerel düzeyde hizmet veren kuruluşlara bağlanan çeşitli danışma kurulları (advisory boards) aracılığıyla kamunun sürece dâhil olması sağlanmıștır. 
Kurullardan sağlanan bilgiler, programların geliştirilmesi için yararlı birer girdi olarak değerlendirildiğinden danışma kurulları üyelerinin özellikle kuruluştan hizmet alan kişilerden oluşması gerektiği düşünülmektedir (Mikesell\& Mullins, 2011).

Yönetişimle bağlantılı olarak halkın bütçe sürecine katılmasının merkezi ve yerel hizmetler düzeyinde gerekli olduğu görülmektedir. Aslında yerel düzeyde katılımın sağlanmasının çok daha mümkün olduğu söylenebilir. Zaten katılımcı bütçeleme anlayışının ilk uygulanışı da 1980'lerin sonlarında Porto Alegre kentinde gerçekleşmiştir. Daha sonra Brezilya'nın diğer birçok kenti ve bölgesinde de hayata geçirilen katılımcı bütçe uygulamasında vatandaşlar, açık meclis toplantılarına katılarak hangi yatırımların kendileri için en önemli olduğuna karar verirler. Toplantılar, yasama bütçe sürecinden çok önce başlar. Bütçe öncelikleri belirlendikten sonra katılımcılar, delegeleri ve bütçe kurul üyelerini seçerler. Bu temsilciler, nihai bütçe belgesini müzakere etmek için yıl boyunca toplanırlar. Örneğin Brezilya'nın Rio Grande do Sul Eyaleti'nde 2000/1 döneminde 378,000 kişi eyaletin 497 belediyesindeki katılımcı bütçe müzakerelerine katılmıştır (Norton\& Elson, 2002: 42).

Schneider\& Goldfrank (2002: 20), Porto Alegre'den çok daha büyük bir nüfusa ve coğrafyaya sahip Rio Grande do Sul'da katılımcı bütçe uygulamasının gerçekleşmesiyle katılımcı bütçenin daha büyük gruplar için de mümkün olduğunun ve katılımın verimli çalışma ve etkili planlamada bir kapasite kaybı anlamına gelmeyeceğinin anlaşıldığını belirtmektedir.

Arnavutluk, Brezilya, Bolivya, Çek Cumhuriyeti, Kanada, İrlanda, Hindistan, Uganda, Birleşik Krallık, Romanya ve Güney Afrika yerel yönetimlerinde de çeşitli yerel çıkar gruplarının resmi olarak bütçe geliştirme ve yürütme faaliyetlerine katıldığı ve bütçe sürecinden önce ve bütçe süreci boyunca vatandaşların sürece dâhil edildiği uygulamalar bulunmaktadır (Mikesell\& Mullins, 2011). Bu açıdan yerel düzeydeki deneyimler, katılımcılıkla ilgili önemli bilgiler edinilmesini sağlamıştır. Bunları özetlememiz gerekirse (Tanaka, 2007: 145);

-Katılımcılardan edinilen görüşler sadece tavsiye niteliğinde ise bunların ne derecede hesaba katılacağı vatandaşlarca bilinmelidir. Aksi takdirde popülist beklentiler, yerine getirilemeyecek taleplere neden olacaktır. 
-Karar verme sürecinin başlarında kendilerine başvurulursa katılımcıların sürece kendilerini dâhil hissetmeleri sağlanacaktır. Aksi halde kararlara etki etme şanslarının olmadığını düşüneceklerdir.

-Hükümet görevlileri ve politikacılar, tehdit edildiklerini ya da devre dış1 bırakılacaklarını hissetmedikleri sürece katılımcı faaliyetlere karşı daha duyarlı ve işbirlikçi olacaklardır.

Bu noktada Türkiye'deki gibi yerel yönetim birimlerinin öz kaynaklarını belirleme yani mali özerklik düzeylerinin kısıtlı olması durumunda halkın yerel hizmet ve harcama bileşimlerini etkileme gücünün de sınırlı kalacağ ifade edilmelidir.

Türkiye'de yerel yönetimler düzeyinde halkın bütçe sürecine katılımı konusunda ayrı yasal bir altyapı yoktur. Ancak 5393 sayılı Belediye Kanunu'nun ilgili maddelerinde Türkiye'de yerel düzeyde katılımla ilgili düzenlemeleri bulmak mümkündür.

"Muhtar, mahalle sakinlerinin gönüllü katılımıyla ortak ihtiyaçları belirlemek ve mahallenin yaşam kalitesini geliştirmekle yükümlü" tutulmuştur (md.9). Mahalle sakinlerinin görüşlerini belirtebilmeleri için nasıl bir platform oluşturulacağı ve tüzel kişilikleri ve ayrı bir bütçeleri olmayan mahallelerin, belirtilen katılımı ve yaşam kalitesi artışını nasıl sağlayabileceği ise belirsizdir.

"Hemşehrilerin, belediye karar ve hizmetlerine katılma, belediye faaliyetleri hakkında bilgilenme hakları olduğu" belirtilmiştir (md.13). Gerçekten belediye meclis toplantıları halka açıktır ve kesinleşen kararlar, yedi gün içinde kamuoyuna açıklanır. Ayrıca birçok belediyede beyaz masa, e-şikâyet gibi kent sakinlerinin istek ve şikâyetlerini internet ya da telefonla iletebilecekleri yöntemler uygulanmaktadır. Belediyeye iletilen dilek ve şikâyetlerle ilgili 3071 sayılı Yasa gereği dilekçe sahibine otuz gün içinde cevap verilmesi gerekmektedir. Aynı ssekilde belediye hizmetleri veya bir işlemle ilgili bilgi sahibi olmak istenirse 4982 sayll kanuna göre bilgi edinme hakkı kullanılabilir. İstenen belge veya bilgiye erissim, belediye tarafından 15 gün içinde sağlanmalıdır.

Vatandaşların, meclis görüşmelerini takip ederek bütçenin nasıl sonuçlandığını izlemeleri mümkün olmakta ancak hazırlık sürecine katılımları ya da kendilerine ön bilgilendirme yapılması söz konusu olmamaktadır. Belediye hizmetlerinin benimsenmesi ve desteklenmesi 
açısından vatandaş katılımının bütçe, beş y1llık stratejik plan ile yıllık performans programı belgelerinin hazırlık sürecinde gerçekleşmesi faydalı olur. Bütçe taslağ ortaya çıktıktan sonra bütçeyle ilgili bilgiler kamuoyu ile paylaşılmalı, katılımcı süreçlerdeki hangi tekliflerin dikkate alındığı, hangilerinin alınmadığı ve nedenleri belirtilmelidir.

"Belediyenin, hemşehriler arasında sosyal ve kültürel ilişkilerin geliştirilmesi ve kültürel değerlerin korunması konusunda gerekli çalışmaları yaparken üniversitelerin, kamu kurumu niteliğindeki meslek kuruluşlarının, sendikaların, sivil toplum kuruluşları ve uzman kişilerin katılımını sağlayacak önlemleri alacağı" (md.13) düzenlemesi de paydaş katılımının önünü açan düzenlemelerdendir. Ayrıca sayılan kuruluş ya da örgüt temsilcileri ile mahalle muhtarları ve ildeki kamu kuruluşlarının amirleri, oy hakkı olmaksızın kendi görev ve faaliyet alanlarına giren konuların görüşüldüğü ihtisas komisyonu toplantılarına katılarak görüş bildirebilirler. Komisyon raporları da halka açıktır.

"Belediye, belde sakinlerinin belediye hizmetleriyle ilgili görüş ve düşüncelerini tespit etmek amacıyla kamuoyu yoklaması ve araştırması yapabilir" (md.15). Bu yoklamalar, seçim öncesi dönemle sınırlı kalmadığı ve özellikle bütçe hazırlanmadan önce kent sakinlerinin beklentilerini tespit etmek amacıyla yapıldı̆̆ı sürece bütçe politikasının yerel tercihler doğrultusunda şekillenmesi mümkün olacaktır. Kamuoyu görüşünün ne kadar dikkate alındığı da ayrıca önemlidir.

Hesap verebilirlik açısından da önemli bir düzenleme "belediye başkanının stratejik plân ve performans programına göre yürütülen faaliyetleri, belirlenmiş performans ölçütlerine göre hedef ve gerçekleşme durumu ile meydana gelen sapmaların nedenlerini ve belediye borçlarının durumunu açıklayan faaliyet raporunu kamuoyuna açıklamasıdır" (md.56).

Belediye Kanunu'nun ilgili maddelerinde katılım ve kararların kamuoyuna duyurulması konusunda birçok düzenlemeye yer verdiği görülmektedir. Gerçekten performans programları, faaliyet raporları, stratejik plan, bütçe kesin hesapları gibi belgeler, belediyelerin internet siteleri vasitasıla kamuoyu erişimine açılmaktadır. Bilgilendirmenin önemli ancak yeterli olmadığı tekrar vurgulanmalıdır. Bu doğrultuda maddelerde belirtilen halkın, sivil toplum örgütlerinin ya da diğer meslek kuruluşlarının kararlara katılımlarının nasıl sağlanacağı tamamen belediyelerin insiyatiflerine bırakılmış gözükmektedir. Hatta belediyelerde belediye başkanının ağırlı̆̆ 
dikkate alınarak katılımın, başkanın insiyatifine bırakılmış olduğu ileri sürülebilir. Bu, Brezilya'da Recife kentinde belediye başkanının katılımcı bütçe sürecini her yıl kendi taraftarlarınca düzenlenen karnavala para aktaran bir modele dönüştürmesi (Kerimoğlu, Güngör\& Koyuncu, 2009; 58) örneğinde olduğu gibi belediye bürokrasisi tarafından yönlendirilen tek taraflı bir katılıma zemin hazırlama riski taşımaktadır.

Ayrıca anılan kanunun 76.maddesindeki katılımla ilgili belki de en önemli yapı olan "kent konseyinde oluşturulan görüşlerin belediye meclisinin ilk toplantısında gündeme alınarak değerlendirileceği” ibaresi, bu görüşlerin yalnızca bir tavsiye niteliğinde olduğunu ve bağlayıcılıklarının olmadığını göstermektedir.

\section{Ulusal Düzeyde Katılımcı Bütçeleme}

Bütçe süreçlerine ulusal düzeyde katılımı, halkın -vatandaş, sivil toplum kuruluşları, işletmelerin- yanı sıra yürütmenin, yasamanın ve denetimin katılımlarının bir toplamı olarak görmek gerekir.

Yerel düzeyde daha çok yatırım ya da faaliyetlerle ilgili kararların verilmesinde etkili olması beklenen katılımcılığın, ulusal düzeyde toplumun gelişimi ve kamusal malların sunumunun iyileştirmesiyle ilgili olduğu söylenebilir.

Coğrafi uzaklık, merkezden alınacak kararlara birebir katılımı zorlaştıracaktır ki bu durum var olan internet teknolojisiyle çözülebilecek durumdadir. Ancak bunun için öncelikle verileri toplamak, işlemek, saklamak ve analiz edebilmek için gerekli altyapının oluşturulması gerekmektedir. Detaylı, maliyetli ve teknik bilgi gerektiren konularla ilgili katılım, meslek örgütleri gibi o alanda uzman gruplarca gerçekleştirilirse anlamlı olacaktır.

Katılımcı bütçeleme uygulamasında yıl boyunca gerçekleştirilecek birden çok forumla vatandaşların tercihlerini açıklama şansı bulması ve dezavantajlı kesimlerin de karar alma süreçlerine dâhil olması mümkün olabilir. Bu noktada öncelikli hedef, sağlıklı oluşmuş bir kamuoyunun varlığı şartına bağlı olarak katılım süreçlerinin farklı sosyo-ekonomik gruplara dâhil pek çok kişiyi kapsayacak bir yapıda olmasıdır. İkincisi, vatandaşların katılım sonucu uzlaştıkları görüşlerin kamusal kararlar üzerindeki etkisinin ve bağlayıcılığının sağlanmasıdır. Böylece katılımın sürekliliği ve olumlu katkısı mümkün olacaktır. 
Katılımcı bütçenin ulusal düzeyde uygulanabilirliği ile bazı endişeler dile getirilebilir. Örneğin bütçe içinde yer alan politik, sosyal ve ekonomik konular ve teknik detaylar hakkında bilgi sahibi olmaya gönüllü olacak ve buna zaman ayırabilecek bir kitlenin bulunması ayrı bir sorun; daha fazla kişinin zaten karışık olan bütçelemeye dâhil olmasıyla sürecin daha karmakarışık bir hale gelme riski ayrı bir sorundur. Bütçe uzmanları ve kamu yetkilileri, vatandaş katılımının yeterli bilgisi olmayan ve bu nedenle yerinde seçimler yapamayacak bir kamuoyuna danışılması anlamına gelebileceğinden endişe edebilirler.

$\mathrm{Bu}$ sorunlardan ilki, devletin uzman olmayan kişilerin de bütçeyi anlamalarını sağlayacak vatandaş bütçeleri gibi dokümanları üretmesi ile aşılabilir. İkincisi ise, kamu bürokrasisi ve akademisyenler dışında bağımsız bir bütçe analizi yapacak kapasitede bir topluluğun oluşması için eğitim çalışmalarının yapılması ile aşılabilir. Örneğin ABD'de karmaşık konularda halkın yapıcı ve yararlı tartışmalara katılmalarını sağlayacak çalışmalar yapan sivil toplum kuruluşları bulunmaktadır. Bunlardan biri olan Sorumlu Federal Bütçe Komisyonu, bütçe ve bütçe süreci hakkında kamuoyunu eğiten iki partili bir organizasyondur. Komisyon, Zor Seçimler Uygulamas1 (The Exercise in Hard Choices) uygulaması adında bir katılımcı bütçe simülasyonu oluşturmuştur. Bir sivil toplum kuruluşu olan Viewpoint Learning de ABD nüfusunun istatistiksel temsil kesitlerinden oluşan üç grupla sekiz saatlik seanslarla Seçim Dialogları (ChoiceDialogues) gerçekleştrimektedir. Bu kuruluşların çalışmaları, halk katılımının güvenilir ve sağlam kararları alma ve destekleme konusunda yeterli olduğunu göstermektedir (Tanaka, 2007: 150).

Tablo- 3: Türkiye'ye IBP Tarafından Geliştirilmesi Tavsiye Edilen Açık Bütçe Anketi Göstergeleri

\begin{tabular}{|c|c|}
\hline na öncesi izler & \\
\hline Halk katılımı için yasal gereklilikler & Mevcut değil \\
\hline Halk katılımının amaçlarının belirlenmesi & Mevcut değil \\
\hline $\begin{array}{l}\text { Denetim raporlarının ötesinde Sayıştay'ın denetim } \\
\text { raporları ile kurulan iletişim }\end{array}$ & Mevcut değil \\
\hline \multicolumn{2}{|l|}{ Danışma süreci } \\
\hline $\begin{array}{l}\text { Bütçe planlama sürecine katılım için yürütme } \\
\text { tarafından geliştirilen mekanizmalar }\end{array}$ & $\begin{array}{l}\text { Mevcut } \\
\text { zayif }\end{array}$ \\
\hline $\begin{array}{l}\text { Makroekonomik bütçe çerçevesine ilişkin yasama } \\
\text { organında kamusal oturum }\end{array}$ & $\begin{array}{l}\text { Mevcut } \\
\text { zayif }\end{array}$ \\
\hline $\begin{array}{llll}\text { Belirli kurumların bütçelerine } & \text { ilişkin } & \text { yasama } \\
\text { organında kamusal oturum } & & \\
\end{array}$ & $\begin{array}{l}\text { Mevcut } \\
\text { zayif }\end{array}$ \\
\hline
\end{tabular}




\begin{tabular}{|c|c|}
\hline $\begin{array}{l}\text { Yasama organındaki bütçe oturumları sırasında halk } \\
\text { için tavsiyede bulunma firsatları }\end{array}$ & Mevcut değil \\
\hline $\begin{array}{l}\text { Bütçenin uygulanması sürecinde halkın katılımı için } \\
\text { yürütmenin geliştirdiği mekanizmalar }\end{array}$ & Mevcut değil \\
\hline $\begin{array}{l}\text { Denetim gündemine katılım için Sayıştay tarafından } \\
\text { geliştirilen mekanizmalar }\end{array}$ & Mevcut değil \\
\hline \multicolumn{2}{|l|}{ Danışmadan sonra izlenecek süreç } \\
\hline $\begin{array}{l}\text { Kamu tarafından yapılan girdilerin kullanımı ile ilgili } \\
\text { yürütmenin yapacağı geribildirim }\end{array}$ & Mevcut değil \\
\hline $\begin{array}{l}\text { Bütçe oturumları ile ilgili raporların yasama tarafından } \\
\text { yayınlanması }\end{array}$ & $\begin{array}{l}\text { Mevcut } \\
\text { zayif }\end{array}$ \\
\hline $\begin{array}{l}\text { Kamu tarafından yapılan girdilerin kullanımı ile ilgili } \\
\text { Sayıștay'ın yapacağı geribildirim }\end{array}$ & Mevcut değil \\
\hline
\end{tabular}

Kaynak: TESEV, 2012.

Halk ve denetim organlarının katılımlarıyla ilgili geliştirilmesi gereken alanlar için Tablo-3’teki Türkiye 2012 Açık Bütçe Anketi sonuçlarına bakmak yeterlidir. Buradan halk katılımıla ilgili yasal mekanizmaların oluşturulmadığı, bütçe tasarısı meclise gelmeden vatandaşların katılımlarının sağlanmadığı ve bütçe ve denetim sonrası vatandaşlara geribildirim yapılmadığı görülmektedir.

Bütçeleme sürecine vatandaş katılımı, kamu mali yönetiminde görece yeni bir uygulamadır ve denetimle ilgili olarak yetkili kuruluşlar dışında vatandaş denetim isteği sistemi, sosyal denetim gibi mekanizmaların geliştirilmesi önerilmektedir. Vatandaş denetim isteği sistemi (citizen audit request system) uygulanan ülkelerde bir hizmetin etkin veya adil yürütülmediğini, kamu yararına aykırı şekilde kanunların ihlal edildiğini ya da yolsuzluk yapıldığını düşünen belirli sayıdaki kişinin yazılı başvurusu üzerine denetim gerçekleştirilmektedir. Örneğin Kore Cumhuriyeti'nde 2001 yılında geliştirilen bu sistem ile Denetim ve Teftiş Bürosu (BAI) tarafindan AntiYolsuzluk Yasası gereğince 20 yaşından büyük 300'den fazla kişinin, kamu yararı için kurulmuş sivil toplum kuruluşlarının, yerel meclislerin ya da BAI'nin denetimine tabi kuruluş başkanlarının yazılı başvurusu üzerine belirli bir devlet birimi denetlenebilmektedir. Ülkemizde de vatandaşların, kamu görevlilerinin etik davranış kurallarına aykırı davrandığı iddiasıyla Başbakanlık Kamu Görevlileri Etik Kurulu'na başvurmaları, 2005 tarihli Kamu Görevlileri Etik Davranış İlkeleri ile Başvuru Usul Ve Esasları Hakkında Yönetmelik ile mümkün kılınmıştır. Kurul, incelemesini en geç üç aylık süre içinde bitirerek üye tam sayısının salt çoğunluğu ile karar verir. Yine 4483 sayılı Memurlar ve Diğer Kamu Görevlilerinin Yargılanması 
Hakkında Kanun'a göre Cumhuriyet başsavcıları, kamu görevlilerinin işledikleri suçlar hakkında soyut ve genel nitelikte olmayan ciddi kanıtlarla desteklenen bir ihbar veya şikâyet aldıklarında önce ilgili makamdan soruşturma izni ister. Hangi görevlilerle ilgili soruşturma izninin hangi makamdan alınacağı kanunda sayılmıştır. Başvurulan ilgili makam, bir ön inceleme yaparak soruşturma izni verilip verilmeyeceğine karar verir. Görüldüğü gibi kamu görevlilerinin görevleri ile ilgili suçlar, gelen ihbarın Cumhuriyet başsavcısı tarafından ciddi ve somut bulunur ve soruşturma izni verilirse incelenebilmektedir.

Türkiye'de bütçe planlama sürecine yasama organının katılımı, Plan ve Bütçe Komisyonları ile Genel Kurul Bütçe Görüşmeleri sırasında sınırlı bir şekilde sağlanmaktadır. Ancak yürütmenin yasama organı üyeleriyle bütçe önceliklerinin belirlenmesi noktasında bir görüş alışverişi yaptığını söylemek pek mümkün değildir.

Yasama organının katılımıyla ilgili eksiklikler mevcuttur. Örneğin bütçenin hazırlanma süreci Orta Vadeli Programın (OVP) kabul edilmesiyle başlamaktadır. OVP, eski düzenleme ile Mayıs ayının sonuna kadar, 2011 yılında yapılan yeni düzenlemeyle Eylül ayının ilk haftası sonuna kadar kabul edilerek Resmi Gazete'de yayımlanmaktadır. OVP ile uyumlu olacak şekilde hazırlanan Orta Vadeli Mali Plan (OVMP) ise eskiden Haziran ayının on beşine kadar 2011 yılında yapılan yeni düzenleme ile en geç Eylül ayının on beşine kadar yayımlanmaktadır. Bütçe Tasarısı'nın meclise sunulması için son gün 17 Ekim olduğuna göre bütçe hazırlama sürecinin kısaltıldı̆̆ı ve yasama organının incelemesini zorlaştırdığı söylenebilir.

Bütçe tasarısı, program bazında ve ayrıntılı performans kriterleri ile birlikte hazırlanmamakta; harcama ve finansman planları ile makroekonomik hedefler ve çıktı ve sonuçlar arasındaki ilişkiyi göstermemektedir.

5018 Sayılı Kanun ile Merkezî yönetim kapsamındaki kamu idarelerinin bütçeleri arasındaki ödenek aktarmalarının kanunla yapılacağı belirtilmiştir. Buna karşın bütçe kanunlarıyla belirlenen ödenekten fazla yapılan harcamalar, kesin hesap kanunlarına konularak sonradan Meclis onayına sunularak kabul edilebilmektedir. Bu şekilde y1l içinde yapilan ödenek üstü harcamalar yasalarda yer almasa da kullanilabilmektedir.

Cumhurbaşkanlığı ve Başbakanlık bütçelerine konulan örtülü ödenek kullanımı ile ilgili "Devletin millî güvenliği ve yüksek menfaatleri ile Devlet 
itibarının gerekleri, siyasi, sosyal ve kültürel amaçlar ve olağanüstü hizmetlerle ilgili Devlet ve Hükümet icapları için kullanılmak üzere" ifadeleri oldukça soyut ve belirsizdir.

Bütçe dışı fonların gelir fazlalarının Hazine hesaplarına aktarılması, yasama organından izin alınması yerine yürütme onayına (Maliye Bakanı, Hazine Müsteşarı'nın bağlı olduğu bakan teklifi Başbakan'ın onayına) bırakılmıştır.

Kesin hesap oylamaları, yeni bütçe tasarısı görüşmeleri arasında formalite şeklinde gelişmektedir. Yasamanın bütçe ile ilgili denetimini sağlayabilecek bir uygulama olmasına karşın uygulamada zayıf ve sınırlı bir işlev görmektedir.

\section{SONUÇ}

Kurumların mali hedeflerinin, hesaplarının ve uygulama sonuçlarının kamuya açık olması şeklinde tanımlanabilecek mali saydamlık, kaynakların etkin kullanılması, hesap verebilirlik, mali disiplin ve mali performansin kamuoyu tarafından değerlendirilmesi; katılım ise, mali olayların planlanması, uygulanması ve denetlenmesi açısından gereklidir. Kısacası mali saydamlık ve halk katılımı birlikte uygulandıklarında en üst fayda düzeyine erişilmesi mümkün olacaktır.

Mali saydamlık, bütçe süreçleri, unsurları ve denetim mekanizmalarıyla doğrudan ilişkilidir. Uluslararası kuruluşların çalışmalarında bütçeyle ilgili çeşitli kriterlerden yola çıkarak mali saydamlık düzeyi ile ilgili sonuçlara ulaşılmaktadır. Bu çalışmalardaki sıralamalarda Türkiye'nin çok kötü bir yerde olmadığı ancak gelişmiş ülkelerin gerisinde olduğu görülmektedir.

Türkiye'deki mevcut düzenlemelerin, bilgi ve belgelerin kamuoyuna açıklığı ile ilgili olumlu bir etki yarattığını; bütçeleme sürecine kamuoyu katılımı anlamında ise herhangi bir ilerleme yaratmadığını söyleyebiliriz. Öncelikle teknik belgelere ulaşabiliyor olmak, bunları değerlendirebilmeyi mümkün kılmamaktadır. Bu anlamda herkesin anlayabileceği bir basitlikle bu belgelerin özetlenerek sunulması gerekmektedir.

Katılımcı bütçelemenin en önemli unsurlarından biri, aktif vatandaşlıktır. Gerçekleştirilecek projelerle ilgili kamuoyu yoklamaları, bütçe öncesi yapılacak ön sunumlar, hizmet kalitesinin, değerlendirilmesini sağlayacak anketlerle seçim arası dönemlerde halka başvurulmasını mümkün kılacak tekniklerin hayata geçirilmesi gerekmektedir. Aynı şekilde sosyal izleme 
araçlarının kullanılması ve sosyal izleme girişimlerinin desteklenmesi gerekmektedir.

Mevzuat, katılımla ilgili genellikle tavsiye niteliğinde sayılabilecek hükümleri düzenlemektedir. Nasıl yapılacağı, sonuçları ve müeyyidelerinin neler olacağ1 belirtilmediğinde temenni düzeyinde kalacak katılım mekanizması, hukuki bir temele oturtulmalıdır. Yerel yönetim düzeyinde katılımla ilgili en somut düzenleme olan kent konseyleri, yalnızca görüş bildiren değil kararlara doğrudan etki eden bir birim haline getirilmeli ve ulusal düzeyde de benzer bir kurum oluşturulmalıdır.

\section{KAYNAKÇA}

ASIAN DEVELOPMENT BANK (2007), Improving Local Governance and Service Delivery: Citizen Report Card Learning Tool Kit, (erişim adresi: http://www.citizenreportcard.com/crccom/crc/pdf/manual.pdf),(erişim tarihi: 20.04.2016).

BOVAIRD, T., Loeffler, E.\& Martin, J. (2003) "From Corporate Governance to Local Governance: Stakeholder-Driven Community Score-Cards for UK Local Agencies?", International Journal of Public Administration, 26, ss.8-9, 10351058, DOI: $10.1081 /$ PAD-120019359.

CGG (2005), Social Audit: A Toolkit A Guide for Performance Improvement and Outcome Measurement, Hyderabad: India.

ÇAVUŞOĞLU, A. T. (2008), "Türkiye'de Kamu Gelirleri ve Harcamaları Arasındaki İlişki Üzerine Ekonometrik Bir Analiz", Dumlupinar Üniversitesi Sosyal Bilimler Dergisi, Say1 20, Nisan 2008.

ERGEN, Z. (2012), "Yönetimden Yönetişime: Katılımcı Bütçeleme Modeli", Maliye Dergisi, Say1 163, Temmuz-Aralık, 316-334.

EUROPEAN PUBLIC SECTOR INFORMATION (2013), Fiscal Transparency And Open Government Data, No. 2013/11, (erişim adresi: https://www.europeandataportal.eu/sites/default/files/library/201311_fiscal_ transparency_and_open_government_data.pdf), (erişim tarihi: 06.04.2016).

IBP (2015), Open Budget Survey, (erişim adresi: http://internationalbudget.org/wpcontent/uploads/OBI2012-TurkeyCS-English.pdf), (erişim tarihi: 10.04.2016).

IBP (2016a), Guide to Transparency in Government Budget Reports: How Civil Society Can Use Budget Reports for Research and Advocacy, (erişim adresi: http://www.internationalbudget.org/wp-content/uploads/Guide-to-

Transparency-in-Government-Budget-Reports-How-Civil-Society-Can-Use-BudgetReports-for-Research-and-Advocacy-English.pdf), (erișim tarihi:18.04.2016).

IBP (2016b), Guide to Transparency in Government Budget Reports: Why are Budget Reports Important, and What Should They Include? (erişim adresi: http://www.internationalbudget.org/wp-content/uploads/Guide-toTransparency-in-Government-Budget-Reports-Why-are-Budget-ReportsImportant-and-What-Should-They-Include-English.pdf), (erişim tarihi: 18.04.2016).

IMF (2014), Update On The Fiscal Transparency Initiative, IMF Policy Paper, Washington, (erişim adresi: http://www.imf.org/external/np/pp/eng/2014/061614.pdf), (erişim tarihi: 05.03.2016

KERİMOĞLU, B., Güngör, H.\& Koyuncu, E. (2009) Belediye bütçesi nasıl izlenir? Yerel Paydaşlar İçin Bir Rehber, Ankara: Tepav Yayınları. 
KOVANCILAR, B.\& Uğur, A. (2011), "Mali Konseyler ve Ülke Deneyimleri”, Maliye Dergisi, Say1 160, Ocak -Haziran, ss. 86-110.

LOPEZ-ACEVEDO, G., Krause, P.\& Mackay, K. (2012), Building Better Policies: The Nuts and Bolts of Monitoring and Evaluation Systems, World Bank Publications.

MIKESELL, J. L.\& Mullins, D. R. (2011), "Reforms for Improved Efficiency in Public Budgeting and Finance: Improvements, Disappointments, and Work-inProgress", Public Budgeting \& Finance, 31, ss.1-30. doi: 10.1111/j.15405850.2011.00998.x

NORTON, A.\& Elson, D. (2002) What's Behind the Budget? Politics, Rights and Accountability in the Budget Process, (erişim adresi: http://www.odi.org/sites/odi.org.uk/files/odi-assets/publications-opinionfiles/2422.pdf), (erişim tarihi: 20.04.2016).

OECD (2015), OECD Best Practices for Budget Transparency, (erişim adresi: http://www.oecd.org/gov/budgeting/best-practices-budget-transparency.htm), (erişim tarihi: 06.04.2016).

PETRİE, M.\& Shields, J. (2010) "Producing a Citizens' Guide to the Budget: Why, What and How?", OECD Journal on Budgeting, Volume 2010/2.

SCHNEIDER, A.\& Goldfrank, B. (2002), Budgets and Ballots in Brazil: Participatory Budgeting from the City to the State, IDS Working Paper: England.

TANAKA, S. (2007), "Engaging the Public in National Budgeting: A Non-Governmental Perspective", OECD Journal on Budgeting, Volume 7, No. 2, 139-177.

TESEV (2012), "Açık Bütçe Endeksi 2012- Türkiye”, (erişim adresi: http://tesev.org.tr/wp-content/uploads/2015/11/Acik_Butce_ Endeksi_2012_Turkiye_Raporu.pdf), (erissim tarihi: 28.03.2016).

WILD, L.\& Harris, D. (2011), "The Political Economy of Community Scorecards in Malawi", (erișim adresi: http://www.odi.org/sites/odi.org.uk/files/odiassets/publications-opinion-files/7543.pdf), (erișim tarihi: 06.03.2016).

WORLD BANK (2016a), "Module 7: Fiscal Transparency", (erișim adresi: http://siteresources.worldbank.org/PUBLICSECTORANDGOVERNANCE/Resour ces/285741-1326399585993/ModuleFiscalTransparency.pdf), (erişim tarihi: 15.04 .2016$)$.

WORLD BANK (2016b), "Participatory Budget Formulation", (erișim adresi:http://web.worldbank.org/WBSITE/EXTERNAL/TOPICS/EXTSOCIALDE VELOPMENT/EXTPCENG/O,,contentMDK:20509380 pagePK:148956 piPK:2166 18 theSitePK:410306,00.html), (erissim tarihi: 15.04.2016).

WORLD BANK (2016c), "Community Score Card Process", (erișim adresi: http://siteresources.worldbank.org/INTPCENG/1143333-

1116505690049/20509286/comscorecardsnote.pdf), (erişim tarihi: 06.03.2016). 